\title{
Refugees and Reconstruction disaster management policy eruption of Mount Sinabung
}

\author{
Tonny P Situmorang, Arifin Adil, Faisal Andri Mahrawa \\ Lecturer of Political Science Faculty of Social and Political Sciences, University of North Sumatra
}

\begin{abstract}
The problem faced by the countries in the world including Indonesia in the last decade is a disaster-related problems. Volcanic eruption of Mount Merapi is among the disasters that regularly should be addressed. Activities due to the volcanic eruption is certainly a great danger and risk to the surrounding community. The impact individually very clearly from injuries, death by poverty. Not only that, this eruption also have an impact on the local economy and disrupt infrastructure, environment, and airlines. Mount Sinabung, located in Karo district located in North Sumatra Province is one of the active volcanos in recent years in which last erupted in 1600. However, renewed in 2010. Since 2010 to 2017 regularly experience a volcanic eruption. . empirically, when a disaster occurs, including as a result of the volcanic eruption of Mount Sinabung had only handled by the local government through local governments, NGOs, employers and society. This study is a qualitative study using critical paradigm in analyzing problems eruption of Mount Sinabung disaster. Specifically the study emphasizes the importance of disaster mitigation through the cooperation of stakeholders in overcoming problems in Mount Sinabung disaster. Where not only a problem for refugee assistance such as food, clothing and toiletries. But also solve the problems of refugees and psychological health. Not only was this research in the future will issue a new model in disaster management Sinabung.
\end{abstract}

\section{Keywords:Political Disasters, Actor, Mitigation Policies}

\section{INTRODUCTION}

The problems faced by the countries in the world including Indonesia in the last decade is a disaster-related problems. Volcanic eruption of Mount Merapi is among the disasters that regularly should be addressed. Activities due to the volcanic eruption is certainly a great danger and risk to the surrounding community. The impact individually very clearly from injuries, death by poverty. Not only that, this eruption also have an impact on the local economy and disrupt infrastructure, environment, and airlines.(Reddick and Chatfeld, 2015: 351-384)

Mount Sinabung, located in Karo district located in North Sumatra Province is one of the active volcanos in recent years in which last erupted in 1600 . However, renewed in 2010 . Since 2010 to 2017 regularly experience a volcanic eruption.

Sinabung disaster management at this time are substantially focused on government preparedness stage when the eruption occurred. Considering measures preventive (prevent) has not allowed the case when viewed from the aspect kurativ (handling). Therefore, the volcanic eruption of Mount Sinabung can not be prevented despite its adverse effects can be prevented by pre-disaster preparedness.

Since 2010 until 2017 the last regulation on Mount Sinabung disaster has not been able to solve the problems in the handling of displaced victims of
Mount Sinabung in particular Karo district. Some residents have not been able to go home. They have been months in the refugee experience hard times. There are stress, depression commit suicide.

Whereas as a serious disruption of a public utility in Mount Sinabung widespread losses in human life in terms of material, economic or environmental and surpasses the concerned communities to cope using their own resources. (Arsyad, 2002) Since the volcanic eruption of Mount Sinabung in 2010 until the 2017 disaster volcanic eruption Mount Sinabung conducted by the North Sumatra Regional Disaster Management (BPBD). This is done because the volcanic eruption of Mount Sinabung is not a national disaster.

This means that the stakeholders who are the main actors in the response to the eruption of volcanic Mount Sinabung as the Regional Government of the province of North Sumatra (BPBDs Sumatra), the Government of Karo (BPBDs Karo), employers, Social Institutions (NGOs) and the public is still running each without coordination surely. As a result, the focus of disaster management volcanic eruption Mount Sinabung until now only focuses on assistance for refugees. (Dye, 2005)

As; food, toiletries and clothing. Certainly good disaster mitigation are also must pay attention to aspects of health, psychological and refugee relocation adequate and it should be done on an ongoing basis is also a form of preventive 
government to solve the volcanic eruption Mount Sinabung if at any time there. For example; Psychological farmers who farm damaged by the eruption of Mount Sinabung, the losses in terms of material obtained from the victims and the government's solution to the disaster.(McEntire,2014)

Therefore, this article was about to dissect; Refugee Dilemma and Reconstruction of disaster management policies eruption of Mount Sinabung in an effort to overcome the problems of refugees eruption of Mount Sinabung.

\section{METHODS}

This study used qualitative methods. Where researchers collected data by in-depth interviews (depth interview) with the various speakers who have the capacity and capabilityrelated disasters, environmental politics, government, NGOs and communities. In determining the sources of researchers using purposive sampling technique in which researchers directly determine the resource in accordance with the capacity and competence related to this research. Researchers also collected a variety of other forms of qualitative data such as documents that are useful for the development of a deeper understanding of this research.

\section{RESULTS AND DISCUSSION}

\section{A.Coordination of Stakeholders}

Background of the condition, the Indonesian people rightly be resilient in the face of any danger. Society needs to be alert to the vulnerabilities that exist around it. Vulnerability is a state or condition of being in force or the nature / human behavior or society, however, the capacity of some elements need to be improved to suppress vulnerabilities that exist in society. Capacity is the ability of resources in the face of threat or danger. The characteristics of the people who have the toughness among other things that the community has the ability to anticipate, protection to dodge and parry, adapt and recover. A fundamental premise in the strategy towards resilience among others: Keep the community of danger, Keep the danger of society, Living harmony with risk, and Grow develop local wisdom.

According to Hamdani Harahap said;

"In disaster management discourse Mount Sinabung in Karo, North Sumatra is inseparable from the system that has been built so that the understanding of disaster management can be understood comprehensively. National system of disaster management in Indonesia has undergone a lot of progress to date.
Meanwhile, the disaster management policies set forth in Law Number 24 Year 2007 on Disaster Management "(Interview dated 8 August 2017)

According to Chairman of BPBD Martin Sitepu saying;

"Disaster eruption of Mount Sinabung not part of a national disaster for the countermeasures are in North Sumatra regional government in collaboration with local governments Karo." (Interview dated July 2, 2016)

When showing an increasing trendandthe potential danger of Sinabung then be issued Letter of Head of Geological Agency containing observations and recommendations that the area should be evacuated. Letter head BPBD be the basis for Karo regent regent to issue decree on the establishment and extension of status. Emergency

response When emergency response status position of Regional Disaster Management Agency (BPBD) Karo be the earliest ranks to coordinate the relevant parties in the ranks of the Regional Government of Karo in preparation for the evacuation of disaster victims.

Entrepreneurs are an integral part of a disaster in a region in any parts of the world including Indonesia. With limited the government's ability to cope with disasters of North Sumatra natural disaster is an event where many actors then could play a role. For companies, the catastrophic situation is a condition in which the corporate social responsibility or corporate social responsibility (CSR) can be shown.

This is corroborated by the Director of WALHI North Sumatra Dana Tarigan who says:

"The improvement strategies and how employers contribute to disaster management in the eruption of Mount Sinabung need to constantly do, ranging from awareness-raising, strengthening the commitment and increased real contribution to support preparedness and response disaster. Of course the necessary role of all parties to bring awareness to companies, especially to top management, shareholders and owners, that contributes in disaster management in Indonesia is not a burden, but as a part of social investments strategically. "(Interview 9 August 2017).

The decline in the welfare of not only felt socially and economically, but also psychology. Therefore, further handling is intended to grow and 
develop a sense of optimism in looking to the future society after the eruption of Mount Sinabung. Based on the experience so far in Karo, this would require an effort far more serious handling and takes a long time. Communities need to be motivated and then back further developed their identity from the slump caused by the disaster. This is where the relevance of approach to community development / community disaster management.

\section{B.Policy constraints disaster}

Countermeasure During the eruption of Mount Sinabung was limited to post-disaster alone. Law No. 24 Year 2007 on Disaster Management has been issued in response to the need for a reliable system of disaster management in Indonesia.

Since the issuance of this law and continued with the release of Government Regulation No. 21 Year 2008 on the Implementation of Disaster Management, Government Regulation No. 22 of 2008 on Financing and Management Assistance, Government Regulation No. 23 of 2008 on Participation of International Organizations and Foreign Non-Governmental Institutions in Disaster Relief and the Presidential Decree No. 8 of 2008 on the National Agency for Disaster Management,

People's expectations so great will pave the established disaster management in Indonesia so that this new institution is expected to soon be able to cope with any disasters in Indonesia. Although socialization and dissemination of information related to the threat of natural disasters in Indonesia through various media continue to be expressed, but our awareness of the threat is still very minimal. (Muktaf 2006)

Understanding the threat paradigm eruption of Mount Sinabung actually become a reality and will be quickly forgotten with the passing of time and the loss of media coverage that covers Mount Sinabung. Mount Sinabung disaster events show that although this area is getting tremendous attention in preparing their citizens face the danger of eruption, when the actual events occur panic still long enough. Some of the causes of this panic them is the lack of understanding of the characteristics of the threat that this threat is not anticipated well in times of disaster. (Nakamura, 2015)

Condition badly damaged in the area of Mount Sinabung which destroyed much caused by the volcanic ash eruption of Mount Sinabung never considered before, for example handling does not seem serious.

UU no. 24/2007 has mandated the need for an understanding of the characteristics of the threat, risk and planning in anticipation of the eruption of Mount Sinabung in Karo, however because this regulation is still relatively new, the dissemination of the guidelines and their regulatory technical community has not yet reached widespread Karo.

Therefore the eruption of Mount Sinabung disaster management in general is still regarded as incidental activities during emergency response. Handling a comprehensive and thorough at the helm had been there, but on the level of implementation handling Sinabung eruption is still constrained due to lack of understanding and still weak institutional capacity in disaster management and Karo district of North Sumatra.

\section{C.Reconstruction Policy}

Risk identification eruption of Mount Sinabung began with the introduction of a characteristic profile or hazards (hazards assessment), then studied the element at risk in the form of infrastructure and human (vulnerability assessment). Disaster hazard maps as a result of hazards assessment almost all types of disasters are already available in the Karo district of North Sumatra, although still on a small scale. In some districts / municipalities have also prepared maps of disaster-prone areas in a larger scale. (Tonnedy, 2015)

BNPB continues to push for a detailed map of any hazards can be formulated and established by the governor of North Sumatra and Regent of Karo. After the eruption of Mount Sinabung disaster risk identified the type and characteristics, then these risks should be assessed to predict the likelihood of occurrence and impact as a result of volcanic ash Sinabung.

To calculate the probability of damage to buildings / infrastructure may be more easily compared with the prediction of potential disasters will occur. It required a prediction that is based on scientific studies which can be accounted for planning acts priority (risk management plan) is required. The most fundamental difficulty in risk assessment is the unavailability of data records disasters in the past, whereas the incidence of natural disasters, especially disasters are very likely to occur repeatedly in a given period. This trend will be read properly if data is recorded with a complete disaster in a long period of time. (Takeoka, 2015)

For the current BPBDs Karo North Sumatra and prioritize data collection eruption of Mount Sinabung disaster events and building a database of disaster we call DiBi (Indonesian Disaster Data and Information) in Karo, North Sumatra. These data are published in the annual book form as well as featured in our website the final results of this risk assessment is risk maps and risk index map. BPBDs in collaboration with stakeholders in North Sumatra, supported several other stakeholders are currently developing risk maps and risk index to the analysis 
unit Karo. Even the index map that disaster eruption of Mount Sinabung is only seen as a relief and rescue and emergency temporary repairs. It is desirable in all phases of disaster management should be based on an integrated and comprehensive planning in the development plan.

\section{CONCLUSION}

Managing Mount Sinabung disaster can not be done only by way of surprise or incidental, but it must be well planned with good management, well before a disaster occurs through a process called disaster management. Implementation of disaster management is a series of efforts that include the establishment of development policies at risk of the onset of the disaster, disaster prevention activities, emergency response, and rehabilitation. To the eruption of Mount Sinabung in handling the required seriousness in handling. Cooperation Mount Sinabung disaster management would be useful to accelerate the recovery in order to handle more effectively and efficiently. disaster has occurred as a result of many years of stakeholders walk on their own. Good future BPBDs Sumatra, Karo BPBDs will coordinate with NGOs and the public. Reconstruction policy in terms of disaster mitigation in the eruption of Sinabung can be resolved with a maximum with the model recommended researchers.

\section{Buku}

\section{REFERENCE}

Arsyad, Azhar, (2002), Pokok-Pokok Manajemen, Pengetahuan Praktis Bagi Pimpinan dan Eksekutif:Yogyakarta: Pustaka Pelajar.

Creswell, John, (2003), Research Design: Qualitative and Mixed Methods Approach. Thousand Oak: Sage Publication Inc.

Dye, Thomas, (2005), Understanding Public policy, United State : Upper Saddle River, New Jersey.

Sukandarrumidi, (2010), Bencana Alam dan Bencana Anturopogene.Yogyakarta: Penerbit Kanisius.

\section{Jurnal:}

David A. McEntire (2014), The Status of Emergency Management Theory: Issues, Barriers, and

Recommendations for Improved Scholarshipc, Paper Presented at the FEMA Higher Education Conference, Department of Public Administration University of North Texas, hal.23-43.
Muktaf, Akhmad Haifani, (2006), Manajemen Resiko Bencana Gempa Bumi (Studi Kasus Gempa Bumi Yogyakarta 27 Mei 2006). Penelitian ini dilakukan oleh Akhmad Muktaf Haifani di Pusat Pengkajian Sistem dan Teknologi Keselamatan, Instalasi dan Bahan Nuklir, Bapetan Jakarta.

Takeoka, Akemi. Chatfield dan Christopher G. Reddick, (2015), Understanding risk communication

gaps through e-government website and Twitter hashtag content analyses: the case of Indonesia's Mt. Sinabung eruption, Faculty of Engineering and Information Sciences -University of Wollongong Research Online Papers hal.351-384

Tonnedy, Ersyad, (2007), Tahapan Penaggulangan Bencana Situ Gintung Oleh $P K P U$ di Universitas Syarif Hidayatullah jakarta.

Nakamura, Yoichi etc, (2013) Japan's Volcanic Disaster Mitigation Initiatives: Activities of the Commission on Mitigation of Volcanic Disasters, the Volcanological Society of Japan, Technical Note of the National Research Institute for Earth Science and Disaster Prevention, No. 380 ; July, 2013.

Peijunshi, (2007), Integrated Disaster Risk Managementof China dipubklikasi oleh Organisation de cooperation et de developpment economic yang dipublikasi oleh organisation for economic goooperation and depelopmend National Key Technologies R\&D Program pada tanggal 26-27 februari 2007 